\title{
THE MINUTE VOLUME OUTPUT AND THE WORK OF THE HEART IN HYPOTHYROIDISM 1, 2
}

\author{
By MARK D. ALTSCHULE AND MARIE C. VOLK \\ (From the Department of Medicine, Harvard University Medical School, and the Research \\ Laboratories and Medical Service of the Beth Israel Hospital, Boston)
}

(Received for publication February 2, 1935)

Close association between aberrations in the function of the thyroid gland and disturbances in the physiology of the cardiovascular system has long been recognized. Because of the frequent occurrence of evidences of heart disease in patients with thyrotoxicosis many investigators have studied the cardiac minute volume output and other aspects of the circulation in this disease. In hypothyroidism, on the other hand, evidences of disturbed cardiovascular function are less prominent, and the cardiac output accordingly has been less thoroughly investigated.

In 1925, Means (1) reported marked diminution in the cardiac minute volume output in two cases of myxedema studied by Field and Bock. Two years later, Mobitz (2) observed a decrease in the cardiac output in one patient with myxedema, and Kininmonth (3) likewise observed a decrease in two additional cases. The results of the two latter observers are difficult to interpret, since the validity of the original ethyl iodide method (4) which they utilized has been questioned. Several years later, Bansi (5) (6) using the methods of Douglas and Haldane (7) and of Grollman (8), also found decreased cardiac output in three patients with myxedema.

The recent work of Blumgart and his associates (9) (10) (11) in establishing the value of total ablation of the normal thyroid gland in the treatment of chronic intractable heart disease made it advisable to study the cardiac output and related aspects of the circulation in hypothyroidism induced by this operation.

\section{MATERIAL AND METHODS}

Observations have been made on seven patients in whom hypothyroidism developed subsequent to total abla-

1 This paper is number XVII of the series entitled "Therapeutic Effect of Total Ablation of Normal Thyroid on Congestive Failure and Angina Pectoris."

2 This investigation was aided by a grant from the William W. Wellington Memorial Research Fund of Harvard University. tion of the thyroid gland performed for the relief of angina pectoris. Studies were made in two, both before, and at different levels of basal metabolism after operation; in one other, observations were made at three different levels of metabolism after operation. Patients with no history of congestive failure were chosen for this study in order to avoid the complicating effect of cardiac decompensation on the output of the heart. Four subjects were males and three females; the ages varied from 53 to 65 years. Several patients showed slight elevation of the blood pressure; all presented slight to moderate sclerosis of the peripheral arteries. The hemoglobin in every instance was 90 per cent or above. Studies were made only in patients with hypothyroidism who could be trained to breathe as deeply and as rapidly as is necessary for measurement of the cardiac output by the acetylene method. The decreased oxygen consumption in hypothyroidism results in a diminution of the oxygen difference between the consecutive gas samples taken for analysis. This increases the percentage deviation from the average of repeated measurements of the cardiac output; it was not possible to obtain reliable results in several patients. As indicated in Table I, many patients were receiving small doses of dessicated thyroid gland (Armour) at the time of study.

All measurements were made in the postabsorptive state, under basal conditions with the patients in the semi-recumbent position, after a rest of. one-half to one hour. The basal metabolic rate was first measured in duplicate with a Collins Benedict-Roth spirometer and calculated according to the Aub-DuBois normal standards. The arterial blood pressure was next measured using a mercury manometer with the standard cuff. The figures in the table represent the averages of several readings. The pulse rate was counted twice before each measurement of the cardiac output. Two measurements of the arteriovenous oxygen difference were made by the acetylene method of Grollman (8), three gas samples being taken for each measurement as suggested by Grollman, Friedman, Clark and Harrison (12). The values reported represent the average of two or more measurements made at the same level of basal metabolism. The maximum deviation from the average for any one value of the arteriovenous oxygen difference accepted as reliable was \pm 7.7 per cent and the average deviation from the values reported was \pm 3.3 per cent. The venous pressure was then measured by the direct method of Moritz and Tabora (13) and finally the velocity of blood flow was estimated, using as an index the " arm to tongue" circulation time measured with decholin (14). 
The figures for the velocity of blood flow are the averages of two or more readings which did not differ from each other by more than two seconds. In three instances the velocity of blood flow was not measured on the same day as the cardiac output.

The cardiac minute volume output was calculated from the arteriovenous oxygen difference and the oxygen consumption, the latter being estimated from data obtained during the measurement of the basal metabolic rate. The work of the left ventricle was calculated using the formula of Evans and Matsuoka (15), W $=\mathrm{QR}$ $+\left(\mathrm{wV}^{2} / 2 \mathrm{~g}\right),^{3}$ disregarding the velocity component $\mathrm{wV}^{\mathbf{3}} / 2 \mathrm{~g}$ since it represents only 1 to 3 per cent of the total work.

\section{RESULTS}

Cardiac output and work. The minute volume output of the heart was decreased in all 7 patients with hypothyroidism following total thyroidectomy (Table I, Figure 1). Measurements, made when the basal metabolic rates had decreased to between minus 25 and minus 37 per cent, re-

${ }^{3} \mathrm{~W}=$ work; $\mathrm{Q}=$ cardiac output per unit of time; $R=$ arterial resistance (mean blood pressure $\times 13.6$ ); $\mathrm{V}=$ velocity of blood in aorta; $\mathrm{w}=$ weight of blood; $\mathbf{g}=$ acceleration due to gravity. vealed cardiac indices (cardiac output in liters per square meter of body surface) of only 1.1 to 1.4 (Figure 1) as compared to the normal values of

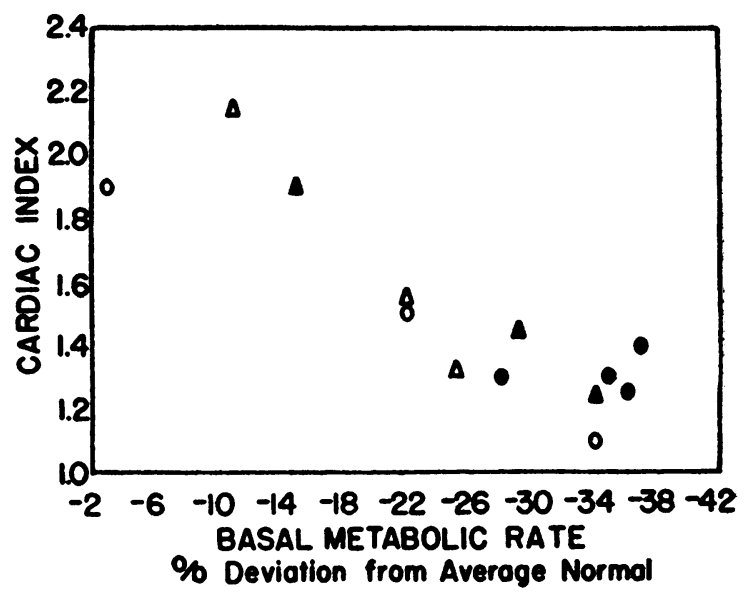

Fig. 1. Relation Between the Basal Metabolic Rate AND THE Cardiac INdex.

The dots indicate measurements made on various patients at a single low level of metabolism. Measurements at various levels of metabolism in three patients are indicated by the circles, and open and closed triangles.

TABLE I

Cardiac output and related observations in hypothyroidism

\begin{tabular}{|c|c|c|c|c|c|c|c|c|c|c|c|c|c|c|c|c|c|c|}
\hline Case & $\underset{4}{8}$ & 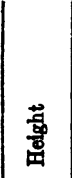 & 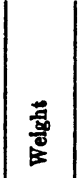 & 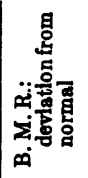 & 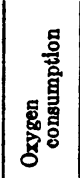 & 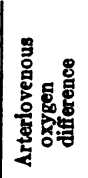 & 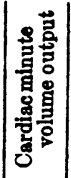 & 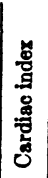 & 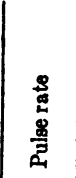 & 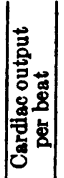 & $\begin{array}{l}\text { s: } \\
\frac{0}{0} \\
\frac{0}{8} \\
\frac{8}{0} \\
\frac{0}{m}\end{array}$ & 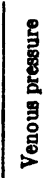 & 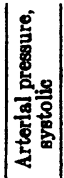 & 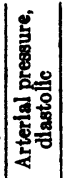 & 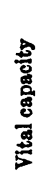 & 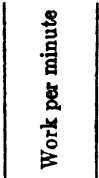 & 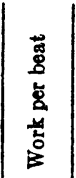 & Remarks \\
\hline & years & inches & pounds & per cent & $\begin{array}{c}c c . p e r \\
\text { minute }\end{array}$ & $\begin{array}{l}\text { volumes } \\
\text { per cent }\end{array}$ & liters & & $\underset{\text { minute }}{\text { per }}$ & $c c$. & seconds & $\mathrm{H}_{2} \mathrm{O}$ & $\operatorname{mm}_{\boldsymbol{H}}$ & $\operatorname{mm}_{\boldsymbol{H} g}$ & $c c$. & $\begin{array}{c}\text { kilogram- } \\
\text { meters }\end{array}$ & $\begin{array}{l}\text { gram- } \\
\text { meters }\end{array}$ & \\
\hline
\end{tabular}

Cases studied after total thyroidectomy

\begin{tabular}{|c|c|c|c|c|c|c|c|c|c|c|c|c|c|c|c|c|c|c|}
\hline $\begin{array}{l}\text { 1. M.P... } \\
\text { 2. R. S.... } \\
\text { 3. T. C... } \\
\text { 4. G. O... }\end{array}$ & $\begin{array}{l}53 \\
58 \\
65 \\
65\end{array}$ & $\begin{array}{l}621 \\
59 \\
70 \\
69\end{array}$ & $\begin{array}{l}137 \\
139 \\
178 \\
194\end{array}$ & $\begin{array}{l}-37 \\
-28 \\
-36 \\
-35\end{array}$ & $\begin{array}{r}133 \\
138 \\
\\
160 \\
167\end{array}$ & $\begin{array}{l}5.85 \\
6.7 \\
6.35 \\
6.5\end{array}$ & $\begin{array}{l}2.3 \\
2.1 \\
2.5 \\
2.5 \\
2.6\end{array}$ & $\begin{array}{l}1.4 \\
1.3 \\
1.2 \\
1.3\end{array}$ & $\begin{array}{l}55 \\
65 \\
46 \\
58\end{array}$ & $\begin{array}{l}41 \\
32 \\
55 \\
44\end{array}$ & $\begin{array}{l}21 \\
16\end{array}$ & $\begin{array}{l}4.1 \\
6.9\end{array}$ & $\begin{array}{l}130 \\
186 \\
138 \\
120\end{array}$ & $\begin{array}{r}86 \\
110 \\
90 \\
76\end{array}$ & $\begin{array}{l}3600 \\
1500 \\
\\
3750 \\
2350\end{array}$ & $\begin{array}{l}3.3 \\
4.1 \\
3.9 \\
3.4\end{array}$ & $\begin{array}{l}61 \\
64 \\
85 \\
59\end{array}$ & $\begin{array}{l}4 \text { months after operation } \\
11 \text { months after operation } \\
\text { Thyroid } 1 / 10 \text { grain daily } \\
101 \text { months after operation } \\
\text { Thyroid } 1 / 10 \text { grain daily } \\
14 \text { months after operation } \\
\text { Thyroid } 1 / 10 \text { grain daily }\end{array}$ \\
\hline
\end{tabular}

Cases studied before and after total thyroidectomy

\begin{tabular}{|c|c|c|c|c|c|c|c|c|c|c|c|c|c|c|c|c|c|c|}
\hline 5. R. B... & 57 & $60 t$ & $\begin{array}{l}164 \\
162 \\
168\end{array}$ & $\begin{array}{l}-11 \\
-25 \\
-22\end{array}$ & $\begin{array}{l}184 \\
156 \\
163\end{array}$ & $\begin{array}{l}\mathbf{5 . 0 0} \\
\mathbf{6 . 6 7} \\
\mathbf{6 . 2 0}\end{array}$ & $\begin{array}{l}3.7 \\
2.3 \\
2.6\end{array}$ & $\begin{array}{l}2.1 \\
1.4 \\
1.5\end{array}$ & $\begin{array}{l}68 \\
60 \\
69\end{array}$ & $\begin{array}{l}54 \\
39 \\
38\end{array}$ & $\begin{array}{l}18 \\
28\end{array}$ & 6.0 & $\begin{array}{l}160 \\
140 \\
140\end{array}$ & $\begin{array}{r}100 \\
82 \\
80\end{array}$ & $\begin{array}{l}1800 \\
1700\end{array}$ & $\begin{array}{l}6.5 \\
3.4 \\
3.9\end{array}$ & $\begin{array}{l}96 \\
57 \\
57\end{array}$ & $\begin{array}{l}\text { Before operation } \\
6 \text { weeks after operation } \\
4 \text { months after operation }\end{array}$ \\
\hline 6. M. S... & 57 & 58 & $\begin{array}{l}107 \\
113 \\
124\end{array}$ & $\begin{array}{l}-3 \\
-22 \\
-34\end{array}$ & $\begin{array}{l}163 \\
135 \\
118\end{array}$ & $\begin{array}{l}5.95 \\
6.23 \\
6.95\end{array}$ & $\begin{array}{l}2.7 \\
2.2 \\
1.7\end{array}$ & $\begin{array}{l}2.0 \\
1.5 \\
1.1\end{array}$ & $\begin{array}{l}73 \\
74 \\
63\end{array}$ & $\begin{array}{l}38 \\
29 \\
27\end{array}$ & $\begin{array}{l}17.5 \\
21 \\
27\end{array}$ & $\begin{array}{l}8.0 \\
7.7 \\
8.9\end{array}$ & $\begin{array}{l}160 \\
164 \\
150\end{array}$ & $\begin{array}{r}90 \\
102 \\
94\end{array}$ & $\begin{array}{l}1550 \\
1550 \\
1500\end{array}$ & $\begin{array}{l}4.7 \\
3.9 \\
2.8\end{array}$ & $\begin{array}{l}64 \\
53 \\
45\end{array}$ & $\begin{array}{l}\text { Before operation } \\
4 \text { months after operation } \\
\text { No thyroid for } 5 \text { weeks } \\
\text { No thyroid for } 7 \text { weeks }\end{array}$ \\
\hline
\end{tabular}

Case studied at various levels of basal metabolic rate after operation

\begin{tabular}{|c|c|c|c|c|c|c|c|c|c|c|c|c|c|c|c|c|c|c|}
\hline 7. 8. F.... & 53 & 64.5 & $\begin{array}{r}163 \\
153 \\
163\end{array}$ & $\begin{array}{l}-34 \\
-15 \\
-29\end{array}$ & $\begin{array}{l}154 \\
193 \\
165\end{array}$ & $\begin{array}{l}6.95 \\
5.85 \\
\\
6.35\end{array}$ & $\begin{array}{l}2.2 \\
3.3 \\
2.6\end{array}$ & $\begin{array}{l}1.2 \\
1.9 \\
1.4\end{array}$ & $\begin{array}{l}56 \\
79 \\
76\end{array}$ & $\begin{array}{l}40 \\
42 \\
\\
34\end{array}$ & $\begin{array}{l}31 \\
22 \\
\\
37\end{array}$ & 3.1 & $\begin{array}{l}110 \\
116 \\
104\end{array}$ & $\begin{array}{l}90 \\
86 \\
76\end{array}$ & $\begin{array}{l}2400 \\
2700 \\
2500\end{array}$ & $\begin{array}{l}3.0 \\
4.5 \\
3.2\end{array}$ & $\begin{array}{l}54 \\
58 \\
42\end{array}$ & $\begin{array}{l}4 \text { months after operation } \\
5 \text { months after operation } \\
\text { Thyroid } 1 \text { grain, t.i.d. } \\
9 \text { months after operation } \\
\text { Thyroid } \& \text { grain every } 3 \text { days }\end{array}$ \\
\hline
\end{tabular}


$2.2 \pm 0.3(16)$. The work of the left ventricle was correspondingly diminished.

The findings in Cases 5 and 6 studied both before and after operation, and in Case 7 studied at different levels of metabolism after operation indicate that as the basal metabolic rate falls, the minute volume output of the heart decreases progressively more rapidly than the oxygen consumption.

Arteriovenous oxygen difference. An increase of arteriovenous oxygen difference became evident at low levels of metabolism (Table I, Figure 2). The disproportionate decrease in the cardiac

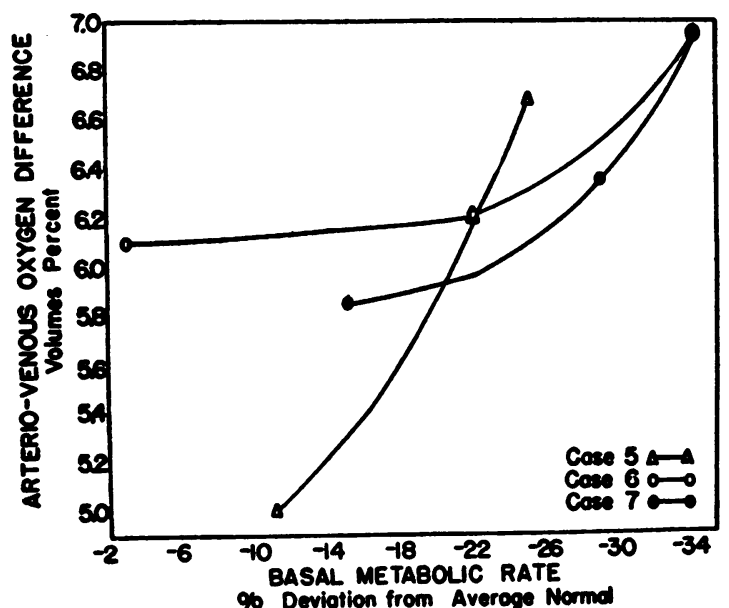

Fig. 2. Relation Between Arteriovenous Oxygen Difference and the Basal Metabolic Rate in Three Patients Studied at Various Levels of Basal MeTABOLISM.

output noted above is associated with this progressive increase in arteriovenous oxygen difference (Cases 5, 6, and 7, Table I). ${ }^{4}$

Velocity of blood flow. The velocity of blood flow was usually decreased when hypothyroidism had developed (Table I). In Cases 3 and 4 the velocity of blood flow was not appreciably less than normal although the cardiac output was strikingly decreased. In some instances, therefore, the velocity of blood flow did not reflect accurately the work of the heart.

Venous pressure, arterial pressure, and vital capacity. The venous and arterial blood pressure

4 Drs. T. R. Harrison and Harold J. Stewart have each studied one case after total thyroidectomy and have also observed this change in the arteriovenous oxygen difference. (Personal communications.) and vital capacity showed no significant changes after total thyroidectomy (Table I).

\section{DISCUSSION}

Starr, Collins, and Wood in 1933 (17) demonstrated a high coefficient of correlation between the cardiac output and oxygen consumption in normal persons under basal conditions. The results of the present study in patients with hypothyroidism indicate, however, that as the basal metabolic rate falls, the minute volume output of the heart decreases progressively more rapidly than the oxygen consumption. This disproportionate decrease in cardiac output in hypothyroidism is accompanied by an increase in the arteriovenous oxygen difference and is in harmony with the observations of Field and Bock in two cases of spontaneous myxedema (1).

The increased arteriovenous oxygen difference found in hypothyroidism is not to be regarded as evidence of heart failure due to "myxedema heart." An increase has in fact been observed after total thyroidectomy in patients with congestive heart failure when the signs of cardiac decompensation were disappearing (unpublished data). The fact that the venous pressure was not increased in the above studied patients with marked hypothyroidism is additional evidence that the circulatory changes were not due to cardiac decompensation. Estimation of the size of the heart on $x$-ray examination before and after operation, furthermore, revealed enlargement after hypothyroidism had developed in only three of the seven patients of this series. The factor responsible for the increased arteriovenous difference has not been ascertained. Further work in this direction is now in progress.

Calculations from the data obtained in this study show that the work of the left ventricle is greatly diminished at low levels of metabolism following total thyroidectomy. This is in harmony with the concept advanced by Blumgart et al. $(9,10,11)$ that the relief obtained in congestive failure and angina pectoris after thyroidectomy is due to lowered demands upon the heart in the hypothyroid state. It is significant that the patients studied experienced relief of their angina pectoris when the work of the heart decreased. Conversely, patients with spontaneous myxedema may 
develop angina pectoris when treated with thyroid (18).

In hypothyroidism the marked decrease in cardiac output with its associated increase in arteriovenous oxygen difference results in a disproportionately greater decrease in left ventricular work than in basal metabolism. At very low levels of metabolism the rest afforded the heart becomes considerably greater than that which might be expected from the decrease in basal metabolic rate alone.

\section{CONCLUSIONS}

1. The minute volume output and the work of the heart are greatly diminished in hypothyroidism following total ablation of the normal thyroid gland.

2. The cardiac output decreases progressively more rapidly than the oxygen consumption as the basal metabolic rate falls in hypothyroidism. This disproportionate decrease in cardiac output is accompanied by a progressive increase in the arteriovenous difference.

3. In most instances the velocity of blood flow was decreased when the cardiac output was low. In some instances, however, the velocity of blood flow did not reflect accurately the work of the heart.

4. The venous pressure, arterial pressure, and vital capacity were not significantly altered after total thyroidectomy in the patients of this series.

\section{BIBLIOGRAPHY}

1. Means, J. H., Circulatory disturbances in diseases of the glands of internal secretion. Endocrinology, 1925, 9, 192.

2. Mobitz, W., Die Ermittlung des Herzschlagvolumens des Menschen durch Einatmung von Äthyljodiddampf. IV. Klinisch kompensierte Veränderungen des Herzens und der Gefässe und beginnende Kreisslaufdekompensation ohne Lungenveränderungen. Deutsches Arch. f. klin. Med., 1927, 157, 359.

3. Kininmonth, J. G., The circulation rate in some pathological states, with observations on the effect of digitalis. Quart. J. Med., 1927, 21, 277.

4. Henderson, Y., and Haggard, H. W., The circulation and its measurement. Am. J. Physiol., 1925, 73, 193.
5. Bansi, H. W., Die Kreislaufgeschwindigkeit beim Morbus Basedow und Myxödem. Klin. Wchnschr., 1928, 7, 1277.

6. Bansi, H. W., and Groscurth, G., Die Kreisslaufleistung beim Basedow und Myxödem. Ztschr. f. klin. Med., 1931, 116, 583.

7. Douglas, C. G., and Haldane, J. S., The regulation of the general circulation rate in man. J. Physiol., 1922, 56, 69.

8. Grollman, A., The determination of the cardiac output of man by the use of acetylene. Am. J. Physiol., 1929, 88, 432.

9. Blumgart, H. L., Levine, S. A., and Berlin, D. D., Congestive heart failure and angina pectoris. The therapeutic effect of thyroidectomy on patients without clinical or pathologic evidence of thyroid toxicity. Arch. Int. Med., 1933, 51, 866.

10. Blumgart, H. L., Riseman, J. E. F., Davis, D., and Berlin, D. D., Therapeutic effect of total ablation of normal thyroid on congestive heart failure and angina pectoris. III. Early results in various types of cardiovascular disease and coincident pathologic states without clinical or pathologic evidence of thyroid toxicity. Arch. Int. Med., 1933, 52, 165.

11. Blumgart, H. L., Berlin, D. D., Davis, D., Riseman, J. E. F., and Weinstein, A. A., Total ablation of thyroid in angina pectoris and congestive failure. XI. Summary of results in treating seventy-five patients during the last eighteen months. J. A. M. A., 1935, 104, 17.

12. Grollman, A., Friedman, B., Clark, G., and Harrison, T. R., Studies in congestive heart failure. XXIII. A critical study of methods for determining the cardiac output in patients with cardiac disease. J. Clin. Invest., 1933, 12, 751.

13. Moritz, F., and v. Tabora, D., Uber eine Methode, beim Menschen den Druck in oberflächlichen Venen exakt zu bestimmen. Deutsches Arch. f. klin. Med., 1910, 98, 475.

14. Gargill, S. L., The use of sodium dehydrocholate as a clinical test of the velocity of blood flow. New England J. Med., 1933, 209, 1089.

15. Evans, C. L., and Matsuoka, J., The effect of various mechanical conditions on the gaseous metabolism and efficiency of the mammalian heart. J. Physiol., 1915, 49, 378.

16. Grollman, A., Physiological variations in the cardiac output of man. VI. The value of the cardiac output of the normal individual in the basal resting condition. Am. J. Physiol., 1929, 90, 210.

17. Starr, I., Jr., Collins, L. H., and Wood, F. C., Studies of the basal work and output of the heart in clinical conditions. J. Clin. Invest., 1933, 12, 13.

18. Means, J. H., and Richardson, E. P., The diagnosis and treatment of diseases of the thyroid gland. Oxford Monographs on Diagnosis and Treatment. Oxford University Press, London, 1929, Vol. 4. 